lowest flowers of the inflorescence are female, and seated in the axils of the sheathing leaves; but the style is enormously elongated so as to carry the stigma to the surface of the water for fertilisation. This recall; the habit of Vallisneria. But, as Mr. Bentham reminds us, the resemblances of Hydrocharidece and of Naiadacece are essentially adaptive, and must not blind us to the real profoundly divergent affinity.

It is worth noting, as a hint to those interested in researches of this fascinating kind, that the investigations of Dr. Hieronymus were made partly on material preserved in a mixture of two-thirds alcohol and one-third glycerine, partly in an aqueous solution of salicylic acid (no further details are given).

W. T. T. D.

\section{PROFESSOR FLOWER}

PROFESSOR FLOWER'S resi'nation of the office of Conservator of the Museum of the Royal College of Surgeons was received at the last meeting of the Council of that body, held on March I3, whereupon it was moved by Sir James Paget, seconded by Mr. Erichsen, and resolved unanimously:- "That the Council hereby desire to express to Mr. William Henry Flower their deep regret at his resignation of the office of Conservator of the Museum of the College.

"That they thank him for the admirable care, judgment, and zeal with which for twenty-two years he has fulfilled the various and responsible duties of that office.

"That they are glad to acknowledge that the great increase of the Museum during those years has been very largely due to his exertions and to the influence which he has exercised, not only on all who have worked with him, but amongst all who have been desirous to promote the progress of anatomical science.

"That they know that, whilst he has increased the value and utility of the Museum by enlarging it, by preserving it in perfect order, and by facilitating the study of its contents, he has also maintained the scientific repute of the College by the numerous works which have gained for him a distinguished position amongst the naturalists and biologists of the present time.

"And that, in thus placing on record their high appreciation of the services of Mr. Flower, the Council feel sure that they are expressing the opinion of all the Fellows and Members of the College, and that they will all unite with them in wishing him complete success and happiness in the i:nportant office to which he has been elected."

The conditions under which the Conservatorship of the Museum of the College will be held in future are at present under discussion, and will probably be decided at the next meeting of the Council on the Ioth inst., when the office will be declared vacant, and candidates invited to send in their applications.

\section{THE DEEP-SEA DREDGINGS OF THE

$$
\text { "TALISMAN"-CRUSTACEA }
$$

$\mathrm{I}$ a previous article attention was called to some of the more remarkable of the deep-sea fishes taken during the recent cruise of the French frigate the Talisman: not less interesting were the numerous forms of Crustacea dredged during the same cruise, a fine collection of which were also on view at the Jardin des Plantes, Paris, as part of the spoils brought home after the voyage. From a survey of the specimens it is evident that these Crustacea are to be found at all depths of the ocean : some pass their lives floating on its surface, feeding thereon or amid the acres of Sargassum weed; while others live at depths of from 4000 to 5000 metres. The so-called swimming crabs which form a section of the Brachyura would seem to be extremely rare at great depths. Certain species taken during the Talisman's cruise are remarkable for their very extensi ve geographical distribution; thus, species of Batynectes which were found at depths of from 450 to 950 metres off the coasts of Morocco and about the Cape Verd Islands, seemed very closely related to the swimming crabs (Portunus) of our own seas, and again to be very nearly connected to species of the same genus collected at the Antilles, in the Mediterranean, and in the Arctic Ocean. Another section of the Brachyura, with sharp triangular bodies (Oxyrrhyncha), contains species which are to be met with at much greater depths; thus Lispognatus thompsoni (A. M. Edw.) was dretged off the coasts of Morocco from depths of between 600 and 1500 metres, and Scyramathia carpenteri was taken at the same place from a depth of I 200 metres. The former of these species has been found in the North Sea, and the latter has been taken off the north of Scotland and in the Mediterranean. The Crustacea intermediate by their forms between the Bracbyura and the Macrura were found in abundance at very great depths, and the forms found see ned in great measure to belong to "transition" forms; so one was often surprised to find a form, which taken by itself appeared abundantly distinct, quite connected with others by numerous intermediary forms. Thus species of Ethusa, Dorippe, Homola, and Dromia seem to present such numerous shades of gradation as to perplex one completely in the difficult task of classifying these genera. Some of these forms are also very remarkable for their geographical distribution: a species of Dicranomia, described by Milne-Edwards from the Antilles, was found off Morocco, and Homola cuvierii, up to this thought to be peculiar to the Mediterranean, was found at the Azores and the Canaries. But the most remarkable instance of the geographical extension of which some genera are capable is furnished by some species of the family Lithodina. These Crustacea to this have been known as inbabitants of the Arctic and Antarctic regions, living in the littoral zone, but now they have been found under the tropics the only difference being that in this latter locality they have contrived to find congenial conditions of life by abandoning their shallow-water life and betaking themselves to the cool depths of over 1000 metres. A fact like this is not without its interest, inasmuch as it shows how some forms can spread themselves from the frozen seas of the north to the seas of the tropics, and so from the region of one Pole to the other; altering their conditions of life as necessity demanded, and resuming thei. old habits when the opportunity to do so again o:curred.

The Crustacea known as Hermit Crabs were found to extend to a depth of 5000 metres; as is well known, the terminal portions of the bodies of these Hermits are soft, not covered like the head and claws of the crab with a strong calcareous shell, and these animals have the habit of tucking the soft part of their bodies for security into the body-whorl of some empty shell; but at the great depths referred to shells suitable for this purpose are not to be found, and the hermit crabs inhabiting these depths must often be in great difficulties for material wherewith to cover themselves. In one specimen taken off Morocco this covering consisted of a living colony of a very pretty species of Epizoanthus.

Species of the family Galatheidea were found in profusion at all depths ; but the colour of their body, generally that of a red or pink hue, was in the forms from the great depths of a uniform white. Some species were found which occupied the interior of those lovely siliceous sponges belonging to the geius Aphrocallistes. One new species, Galathodes antonii, was found at a depth of 4000 metres, and anotlier, from the same depth, with its abdomen coiled twice upon itself, has been also described by A. M. Edwards as new (Ptychogaster formosius).

Of the group of Eryonidæ a considerable number of both genera and species were dredged. Of these, those 